medRxiv preprint doi: https://doi.org/10.1101/2021.02.17.21251707; this version posted February 19, 2021. The copyright holder for this preprint

(which was not certified by peer review) is the author/funder, who has granted medRxiv a license to display the preprint in perpetuity.

It is made available under a CC-BY-ND 4.0 International license .

Reuter et al.

TOF clinical variants \& interacting network

\title{
Clinical genetic risk variants inform a functional protein interaction network for tetralogy of Fallot
}

Miriam S. Reuter ${ }^{1,2,3}$ MD, Rajiv R. Chaturvedi ${ }^{4,5,6}$ MB BChir, MD, PhD, Rebekah K. Jobling ${ }^{6,7,8}$ MD,

Giovanna Pellecchia ${ }^{2}$ PhD, Omar Hamdan ${ }^{2}$ BSc, Wilson W.L. Sung ${ }^{2}$ MSc, Thomas Nalpathamkalam² BSc, Pratyusha Attaluri ${ }^{9}$ MHSc MD, Candice K. Silversides ${ }^{10}$ MD, Rachel M. Wald ${ }^{4,10}$ MD, Christian R.

Marshall $2,8,11 \mathrm{PhD}$, Simon Williams ${ }^{12,13} \mathrm{PhD}$, Bernard D. Keavney ${ }^{12,13} \mathrm{DM}$, Bhooma Thiruvahindrapuram ${ }^{2}$ MSc, Stephen W. Scherer ${ }^{2,3,14,15} \mathrm{PhD}$, Anne S. Bassett ${ }^{10,16,17,18}$ MD

${ }^{1}$ CGEn, The Hospital for Sick Children, Toronto, ON, Canada

${ }^{2}$ The Centre for Applied Genomics, The Hospital for Sick Children, Toronto, ON, Canada

${ }^{3}$ Program in Genetics and Genome Biology, The Hospital for Sick Children, Toronto, Ontario, Canada

${ }^{4}$ Labatt Family Heart Centre, Hospital for Sick Children, Toronto, ON, Canada

${ }^{5}$ Ontario Fetal Centre, Mt Sinai Hospital, Toronto, ON, Canada

${ }^{6}$ Ted Rogers Centre for Heart Research, Cardiac Genome Clinic, The Hospital for Sick Children, Toronto, ON, Canada

${ }^{7}$ Division of Clinical and Metabolic Genetics, The Hospital for Sick Children, Toronto, ON, Canada

${ }^{8}$ Genome Diagnostics, Department of Paediatric Laboratory Medicine, The Hospital for Sick Children, Toronto, ON, Canada

${ }^{9}$ Medical Genomics Program, Department of Molecular Genetics, University of Toronto, Toronto, ON, Canada

${ }^{10}$ Division of Cardiology, Toronto Congenital Cardiac Centre for Adults at the Peter Munk Cardiac Centre, Department of Medicine, University Health Network, Toronto, ON, Canada

${ }^{11}$ Laboratory Medicine and Pathobiology, University of Toronto, Toronto, ON, Canada;

${ }^{12}$ Division of Cardiovascular Sciences, Faculty of Biology, Medicine and Health, The University of Manchester, United Kingdom

${ }^{13}$ Manchester University NHS Foundation Trust, Manchester Academic Health Science Centre, United Kingdom

NOTE: This preprint reports new research that has not been certified by peer review and should not be used to guide clinical practice. 1 
medRxiv preprint doi: https://doi.org/10.1101/2021.02.17.21251707; this version posted February 19, 2021. The copyright holder for this preprint (which was not certified by peer review) is the author/funder, who has granted medRxiv a license to display the preprint in perpetuity. It is made available under a CC-BY-ND 4.0 International license .

Reuter et al.

TOF clinical variants \& interacting network

${ }^{14}$ Department of Molecular Genetics, University of Toronto, Toronto, ON, Canada

${ }^{15}$ McLaughlin Centre, University of Toronto, Toronto, ON, Canada

${ }^{16}$ Clinical Genetics Research Program, Centre for Addiction and Mental Health, Toronto, ON, Canada

${ }^{17}$ The Dalglish Family 22q Clinic for Adults with 22q11.2 Deletion Syndrome, Department of Psychiatry, and Toronto General Research Institute, University Health Network, Toronto, ON, Canada

${ }^{18}$ Department of Psychiatry, University of Toronto, Toronto, ON, Canada

Corresponding author:

Anne S. Bassett

anne.bassett@utoronto.ca

200 Elizabeth Street

Toronto, Ontario M5G 2C4 
medRxiv preprint doi: https://doi.org/10.1101/2021.02.17.21251707; this version posted February 19, 2021. The copyright holder for this preprint (which was not certified by peer review) is the author/funder, who has granted medRxiv a license to display the preprint in perpetuity. It is made available under a CC-BY-ND 4.0 International license .

Reuter et al.

TOF clinical variants \& interacting network

\begin{abstract}
:
Background: Tetralogy of Fallot (TOF), the most common cyanotic heart defect in newborns, has evidence of multiple genetic contributing factors. Identifying variants that are clinically relevant is essential to understand patient-specific disease susceptibility and outcomes, and could contribute to delineating pathomechanisms.
\end{abstract}

Methods and Results: We used a clinically-driven strategy and current guidelines to re-analyze exome sequencing data from 811 probands with TOF, focused on identifying rare loss-of-function and other likely pathogenic variants in congenital heart disease $(\mathrm{CHD})$ genes. In addition to confirming a major contribution of likely pathogenic variants in FLT4 (VEGFR3; $n=14)$ and NOTCH1 $(n=11)$, we identified 1-3 such variants in each of 21 other CHD genes, including ATRX, DLL4, EP300, GATA6, JAG1, NF1, PIK3CA, RAF1, RASA1, SMAD2, and TBX1. There were also three emerging CHD/TOF candidate genes with multiple loss-of-function variants in this cohort: KDR $(\mathrm{n}=4), \operatorname{IQGAP1}(\mathrm{n}=3)$, and GDF1 $(\mathrm{n}=8)$. In total, these variants were identified in 64 probands (7.9\%). Using the 26 composite genes in a STRING protein interaction enrichment analysis revealed a biologically relevant network ( $p$-value 3.3e-16), with VEGFR2 (KDR) and NOTCH1 representing central nodes. Variants associated with arrhythmias/sudden death and/or heart failure indicated factors that could influence long-term outcomes.

Conclusions: The results are relevant to precision medicine for TOF. They suggest considerable clinical yield from genome-wide sequencing, and further evidence for KDR as a CHD/TOF gene and VEGF and Notch signaling as mechanisms in human disease. Harnessing genetic heterogeneity of single gene defects could inform etiopathogenesis and help prioritize novel candidate genes for TOF.

Key words: Congenital heart defect, vascular endothelial growth factor, personalized medicine, genomewide sequencing, genomics 
medRxiv preprint doi: https://doi.org/10.1101/2021.02.17.21251707; this version posted February 19, 2021. The copyright holder for this preprint (which was not certified by peer review) is the author/funder, who has granted medRxiv a license to display the preprint in perpetuity. It is made available under a CC-BY-ND 4.0 International license .

Reuter et al.

TOF clinical variants \& interacting network

\section{Introduction:}

Tetralogy of Fallot (TOF) affects about one in 3000 live births, and is the most common cyanotic heart defect in newborns ${ }^{1,2}$. Initially described in 1671 by Danish anatomist Niels Stensen, the four components (pulmonary outflow tract obstruction, aorta overriding both ventricles, ventricular septal defect, and hypertrophy of the right ventricle) represent a single developmental anomaly ${ }^{3,4}$. Further detailed anatomical documentation by Arthur Fallot, Maude Abbott, and others, laid the foundation first for palliative, and later corrective, surgical procedures ${ }^{4,5}$. Advances in imaging, medical management, and surgeries across the lifespan have transformed TOF from a usually fatal pediatric condition to a chronic disease that is more prevalent in adults than children, with life expectancy into the seventh decade and beyond ${ }^{6-9}$.

The pursuit of determining the genetic underpinnings and recognizing how these may affect late outcomes in TOF, has proceeded in parallel with these clinical advances ${ }^{10-13}$. This research began with the recognition of multi-system syndromes in approximately $20 \%$ of patients, most commonly caused by 22q11.2 microdeletions, other copy number variants, or aneuploidies ${ }^{14}$, along with some single-gene defects ${ }^{15}$. Availability of newer genomic technologies, particularly genome-wide sequencing, has expanded gene discovery studies. The cumulative genetic evidence indicates a pattern of molecular etiology for TOF that is characterized by genetic heterogeneity and some distinction from congenital heart disease (CHD) as a whole ${ }^{14,16-21}$. However, there has been relatively limited consideration of the clinical pathogenicity of genetic variants for TOF and translation of findings into the clinic ${ }^{22,23}$.

The cohort studied here is the largest genome-wide sequencing dataset for TOF ${ }^{20,24}$. Previous research identified clusters of deleterious variants in NOTCH1 and FLT4 which surpassed statistical thresholds for genome-wide significance and were thus considered predisposing to TOF in almost $7 \%$ of the probands; a potential association with TBX1 deleterious variants was also reported ${ }^{20}$. However, many of the NOTCH1 and FLT4 variants constituted missense variants of uncertain significance, according to standard American College of Medical Genetics (ACMG) adjudication guidelines (details on TBX1 variants were not provided) ${ }^{25}$. Besides including abundant variants of uncertain significance, genome-wide variant burden analyses often lack power to detect rare gene-disease associations, which contribute largely to the genetic heterogeneity, and form the basis for defining clinically reportable genetic variants.

The objective of this study was to improve our understanding of variants that are of relevance to clinical practice for patients with TOF. We used ACMG interpretation guidelines to re-analyze the exome 
medRxiv preprint doi: https://doi.org/10.1101/2021.02.17.21251707; this version posted February 19, 2021. The copyright holder for this preprint (which was not certified by peer review) is the author/funder, who has granted medRxiv a license to display the preprint in perpetuity. It is made available under a CC-BY-ND 4.0 International license .

Reuter et al.

TOF clinical variants \& interacting network

sequencing data of 811 probands with TOF, and focused on delineating variants that were considered relevant for the congenital cardiac phenotype. We identified 64 (7.9\%) of 811 pediatric TOF probands to have pathogenic/likely pathogenic variants in known CHD genes $(n=50)$, or loss-of-function variants in emerging CHD/TOF candidate genes ( $n=15$; Figure 1). The implicated genes encode proteins that functionally interact, indicating that the heterogeneous genetic architecture could inform mechanism. Other pathogenic/likely pathogenic variants identified add to potential genetic implications for cardiovascular outcomes.

\section{Methods:}

We studied the exome sequencing data of a multi-centre cohort of probands with TOF, accessed through the European Genome-phenome Archive (EGA ${ }^{26}$; https://www.ebi.ac.uk/ega), study accession EGAS00001003302 ${ }^{20}$. The cohort was reported to be of Northern European ancestry, not to exhibit features of recognized malformation or developmental syndromes ${ }^{27}$, and to have previously excluded 22q11.2 microdeletions by multiplex ligation-dependent probe amplification ${ }^{20}$. We downloaded 829 bam files from EGA, subsequently excluding 18 files that were corrupted, aligned to a different (bwa VN:0.7.6a-r433, b37) reference genome, or duplicates (supplementary information).

For the analyses presented here, we considered $n=811$ unique exome sequencing datasets (Table S1), aligned to GRCh37 (hg19). The data were analyzed at The Centre for Applied Genomics (TCAG, The Hospital for Sick Children, Toronto, Canada) under a research protocol of the Hospital for Sick Children (REB\# 0019980189). We prioritized the dataset for rare variants (substitutions and small insertions/deletions) affecting genes associated with congenital heart defects (https://omim.org/, http://chdgene.victorchang.edu.au/, https://pubmed.ncbi.nlm.nih.gov/; as of September 2020), and other cardiac conditions putatively relevant to outcome (supplementary information). For the yield of pathogenic/likely pathogenic variants, we pursued a conservative interpretation strategy as per ACMG consensus guidelines ${ }^{25}$. Variants covered by less than $10 x$ were omitted, and all reported variants were visualized using IGV (http://software.broadinstitute.org/software/igv/). For candidate genes KDR and IQGAP1, we compared the loss-of-function variant counts to those identified by genome sequencing of two control cohorts: (i) participants in the 1000 genomes project $(n=2,504$ genomes, all ancestries; https://www.internationalgenome.org/), and (ii) parents of European ancestry from the Autism Speaks MSSNG database ( $n=3,697$ genomes in DB6; https://www.mss.ng/). The prevalence of the GDF1 
medRxiv preprint doi: https://doi.org/10.1101/2021.02.17.21251707; this version posted February 19, 2021. The copyright holder for this preprint (which was not certified by peer review) is the author/funder, who has granted medRxiv a license to display the preprint in perpetuity. It is made available under a CC-BY-ND 4.0 International license .

Reuter et al.

TOF clinical variants \& interacting network

stopgain variant p.Cys227* was only compared to the $n=3,697$ European controls from MSSNG, as this variant is known to be more common among Europeans. Functional protein interaction analyses were performed with Cytoscape ${ }^{28}$ software v.3.8.2, using the STRING app ${ }^{29}$.

\section{Results:}

Re-analyzing the exome sequencing data from 811 probands with TOF, we identified five CHDassociated genes with multiple pathogenic/likely pathogenic variants (Figure 1). These included 14 likely pathogenic loss-of-function variants in FLT4 (all loss-of-function), and 11 in NOTCH1 (7 loss-of-function, 4 missense) (Table S2). That we observed the highest prevalence for variants in these two genes, collectively $25 / 811$ (3.1\%), but lower than previously reported variant yields, was expected given findings from studies of this and other cohorts using different adjudication methods ${ }^{18,20,21}$. We also identified three likely pathogenic variants in JAG1 (OMIM-P 187500, 118450), and two each in TBX1 (OMIM-P 187500), and GATA6 (OMIM-P 187500, 600001) (Table S2). Consistent with the genetic heterogeneity of TOF, we identified 16 other individuals to have one pathogenic/likely pathogenic variant (11 loss-of-function, 5 missense) in 16 CHD genes: ARHGAP31, ATRX, CACNA1C, CHD7, CSNK2A1, DLL4, EP300, GATAD2B, KAT6A, LZTR1, NF1, NODAL, PIK3CA, RAF1, RASA1, and SMAD2, and one individual with loss-of-function variants in two genes, ASXL1 and PSMD12 (Table S2). Thus, there were 49 probands in this cohort identified to have at least one pathogenic/likely pathogenic variant in a CHDassociated gene $(49 / 811 ; 6.0 \%)$.

In three emerging CHD candidate genes (KDR, IQGAP1, and GDF1), i.e., with substantial research evidence but as yet insufficient to clinically deem variants "likely pathogenic", we identified multiple loss-of-function variants in 16 individuals in this cohort (Figure 1, Table S3). Four individuals with TOF had high-confidence loss-of-function variants in $K D R$, compared with none in 6,201 controls (Fisher's exact test (FET) $p=1.8 \mathrm{E}-4$; gnomAD observed/expected loss-of-function constraint score (o/e LOF) = 0.15). The significant enrichment found for this large cohort adds further evidence for KDR as a TOF/CHD gene to that provided by several recent studies reporting rare loss-of-function variants in KDR in independent cohorts with TOF or other conotruncal defects ${ }^{18,21,30}$ (Figure S1).

IQGAP1 loss-of-function variants have also been reported in several cohorts of TOF and other CHD ${ }^{18,31,}$ 32. In the TOF cohort analyzed here, there were three individuals with loss-of-function variants in IQGAP1 with significant enrichment compared to 1000 genomes control data (3/811 vs. 1/2,504; FET: $p$ 
medRxiv preprint doi: https://doi.org/10.1101/2021.02.17.21251707; this version posted February 19, 2021. The copyright holder for this preprint (which was not certified by peer review) is the author/funder, who has granted medRxiv a license to display the preprint in perpetuity. It is made available under a CC-BY-ND 4.0 International license .

Reuter et al.

TOF clinical variants \& interacting network

$=4.8 \mathrm{E}-2$; gnomAD o/e LOF $=0.19)$, but at the non-significant trend level compared to control data comprising parents in an autism cohort (3/811 vs. 5/3,697; FET: $p=1.6 \mathrm{E}-1)$. For GDF1, the pathogenicity of biallelic (homozygous or compound heterozygous) variants is well established [OMIM-P 208530] ${ }^{21}$, and heterozygous variants have also been suggested as risk factors for $\mathrm{CHD}^{33}$ [OMIM-P 613854]. In the current exome data, the prevalence of GDF1 heterozygous loss-of-function variants is likely to be underestimated due to insufficient coverage of this locus. Nonetheless, we identified 8 individuals to have such a variant, including an identical, heterozygous GDF1 stopgain variant p.Cys227* in 7 of the 706 unrelated probands having samples with adequate read depths ( $\geq 10 x)$. In comparison, the carrier frequency of this variant was 6 of 3,697 European controls (FET: $p=1.9 E-3$ ), indicating significant enrichment of heterozygous loss-of-function variants in GDF1 in the TOF cohort studied.

Taken together, we identified 64 probands $(7.9 \%)$ with $n=50$ pathogenic/likely pathogenic variants in 23 known CHD genes (Table S2) or $n=15$ loss-of-function variants in 3 emerging CHD/TOF candidate genes (Table S3) in these TOF exome data. We note that the majority of these variants $(41 / 65,63.1 \%)$ and genes $(23 / 26,88.5 \%)$ were not previously reported for this cohort ${ }^{20}$ (Tables S2, S3).

We next considered the 23 identified TOF disease genes that had clinically relevant variants and 3 emerging candidate genes as a group, in an in silico functional interaction analysis. This showed evidence for a highly interactive network of the encoded proteins (STRING interaction enrichment $p$ value 3.3E-16). VEGFR2 (gene KDR) and NOTCH1 were central nodes within this network map, each connecting directly with 11 other proteins. In all, 23 of the 26 genes (88.5\%) form an interactive network, related to VEGFR2 (KDR) or NOTCH1 by $\leq 2$ edges (Figure 2). Pathogenic/likely pathogenic lossof-function variants from an independent cohort of 424 children with TOF ${ }^{21}$ supported, and slightly extended, this network, identifying NOTCH2 as an additional protein with multiple (five) interactions (Table S4, Figure S2). All of the composite genes are expressed in human hearts (https://www.proteinatlas.org/), but at varying levels (Figures 2, S2). A pathway enrichment map for those proteins is provided as supplemental material (Figure S3).

Notably, we additionally identified rare nonsynonymous or predicted splice-altering variants of uncertain significance, according to ACMG interpretation guidelines. In some cases, clinical data or knowledge on the parental genotypes, which were inaccessible for this study, could inform more accurate variant classifications. The majority of NOTCH1 rare nonsynonymous missense and in-frame variants that were previously reported for this sample ${ }^{20}$ were variants of uncertain significance $(n=21$; Table S5). Three of these variants - p.(Glu1294Lys), p.(Gly200Arg) ${ }^{34}$, and p.(Pro143Leu) - were 
medRxiv preprint doi: https://doi.org/10.1101/2021.02.17.21251707; this version posted February 19, 2021. The copyright holder for this preprint (which was not certified by peer review) is the author/funder, who has granted medRxiv a license to display the preprint in perpetuity. It is made available under a CC-BY-ND 4.0 International license .

Reuter et al.

TOF clinical variants \& interacting network

identified in probands with other variants identified as likely pathogenic: NOTCH1 p.(GIn1733*), NF1 c.5206-1G>C, and EP300 p.(Phe1595Val), respectively (Table S5), representing examples of withinindividual allelic or genetic heterogeneity. There were other CHD-relevant genes or candidates with variants of uncertain significance, including loss-of-function variants in CHD4, ECE1, SMAD6, ZFPM1, PRKD1 and VEGFA (Table S5).

We also report pathogenic/likely pathogenic variants for childhood-onset disorders, but with less established evidence at this time for clinical relevance to TOF/CHD (Table S6). These include loss-offunction variants in POLR1A (2x), TCF12 (2x), APC, and GLI2 (Table S6) where, interestingly, the encoded proteins link to the network map for TOF (Figure 2).

To further investigate the potential clinical utility of exome sequencing, we also interrogated the dataset for rare variants with potential clinical implications for cardiovascular management and outcome. In 16 (2.0\%) of the 811 probands we identified pathogenic/likely pathogenic variants meeting these criteria. There were 11 variants associated with cardiac hypertrophy, arrhythmia and sudden cardiac death: hypertrophic cardiomyopathy (MYBPC3 (3x), MYH7, MYL2, TNNI3), arrhythmogenic right ventricular dysplasia (DSP (2x), DSC2), Brugada syndrome (SCN5A), and dilated cardiomyopathy (DMD) (Table S7). There were also five variants in genes (LZTR1, RAF1, CACNA1C, NF1, RASA1) implicated in other conditions, including e.g., Noonan and Timothy syndromes ${ }^{35,36}$, that in addition have been reported to be associated with CHD, thus were considered in the etiologic analysis (Tables S2, S7).

\section{Discussion:}

Precision medicine is an emerging concept that involves health management based on individual characteristics, including genetic disease susceptibilities and pharmacogenomics ${ }^{37,}{ }^{38}$. Delineation of disease-causing and very high impact variants and genes and their functional networks will advance both precision health initiatives and our understanding of the relevant molecular mechanisms. The rationale for re-analyzing this cohort of 811 individuals with TOF was to focus on identifying sequence variants with sufficient evidence for pathogenicity, according to consensus clinical guidelines ${ }^{25}$, that could inform disease etiologies of TOF. We also aimed to detect rare and emerging gene-disease associations, that had not been noted in previous genome-wide enrichment studies of the cohort ${ }^{20}$. We identified 50 pathogenic/likely pathogenic variants for TOF, plus 15 loss-of-function variants in emerging CHD/TOF candidate genes. The majority of variants $(41 / 65,63.1 \%)$ and genes $(23 / 26,88.5 \%)$ were not 
medRxiv preprint doi: https://doi.org/10.1101/2021.02.17.21251707; this version posted February 19, 2021. The copyright holder for this preprint (which was not certified by peer review) is the author/funder, who has granted medRxiv a license to display the preprint in perpetuity. It is made available under a CC-BY-ND 4.0 International license .

Reuter et al.

TOF clinical variants \& interacting network

previously reported for this cohort (Tables S2, S3). Collectively, the results document both genetic and allelic heterogeneity at the clinical level in the pathogenesis of TOF across this large cohort, and in some cases within individual. The findings may also help to define minimal clinical gene panels for TOF.

Likely pathogenic loss-of-function variants in FLT4 (VEGFR3), NOTCH1, and JAG1 were among the most common findings, further confirming a major role for VEGF and Notch signaling in TOF. A dosage effect of VEGF/Notch signaling in outflow tract development and TOF has long been suggested from mouse models ${ }^{39}$, and has been recently substantiated by several human genetic studies ${ }^{18,20,32}$. We also provide further evidence that haploinsufficiency of $K D R$ (encoding VEGF receptor 2 ) and, likely to a lesser extent IQGAP1 (VEGF receptor signaling), contribute to TOF risk. Rare KDR loss-of-function variants were previously reported in several cohorts with TOF and other conotruncal defects $18,21,30$ (Figure S1), and results from the current study of the largest TOF cohort available indicate a significant enrichment compared to controls (FET: $p=1.8 \mathrm{E}-4)$. Other studies report evidence that similar KDR variants are also risk factors for pulmonary arterial hypertension, independent of any heart malformations ${ }^{40,41}$. As for many CHD genes, this suggests pleiotropy for KDR requiring further study. There may also be clinical implications with respect to pulmonary hypertension in TOF ${ }^{42}$. IQGAP1 lossof-function variants were identified in this and various other CHD cohorts ${ }^{18,31,32}$ (including multiple de novo variants), but were also found in some parents of probands with autism. Besides its essential role in VEGF receptor signaling, IQGAP1 regulates and integrates other cellular processes, including neuronal functions ${ }^{43}$. We consider IQGAP1 a promising candidate gene for CHD, but further statistical support and phenotypic characterization will be needed.

Pathogenic/likely pathogenic and candidate variants were identified in a total of 26 genes: ARHGAP31, ASXL1, ATRX, CACNA1C, CHD7, CSNK2A1, DLL4, EP300, FLT4, GATAD2B, GATA6, GDF1, JAG1, IQGAP1, KAT6A, KDR, LZTR1, NF1, NODAL, NOTCH1, PIK3CA, PSMD12, RAF1, RASA1, SMAD2, and TBX1. The results further indicated that the encoded proteins form highly inter-connected networks of functional interaction. This suggests that the genetic heterogeneity identified through human disease studies may help to inform overlapping or unifying molecular pathomechanisms for TOF. Notably, VEGFR2 (KDR) and NOTCH1 form central nodes in this interaction network, supporting and extending evidence that the developing right outflow tract is vulnerable to VEGF/Notch dysregulation ${ }^{44-46}$. VEGF signaling was also found as the top canonical pathway associated with de novo variants in conotruncal defects ${ }^{32}$, and low VEGF expression was linked to TOF risk ${ }^{47}$. Delineating the relevant protein networks and associated pathomechanisms will help to rank novel candidate genes and could inform potential therapeutic 
medRxiv preprint doi: https://doi.org/10.1101/2021.02.17.21251707; this version posted February 19, 2021. The copyright holder for this preprint (which was not certified by peer review) is the author/funder, who has granted medRxiv a license to display the preprint in perpetuity. It is made available under a CC-BY-ND 4.0 International license .

Reuter et al.

TOF clinical variants \& interacting network

targets. For example, loss-of-function variants in TCF12 (Table S4) were recently reported in multiple individuals with unexplained $\mathrm{CHD}^{30}$, and the encoded protein functionally interacts with three confirmed TOF-associated proteins (NOTCH1, SMAD2, EP300).

Even with overlapping molecular functions, however, the phenotypic spectrum (pleiotropy) can vary largely not only from one gene to another, and one variant to another, but for individuals with the same variant within and between families. Most of the identified pathogenic/likely pathogenic variants in CHD genes were associated with multisystemic genetic disorders (Table S2), as expected for confirmed genes in early stages of clinical interpretation. Clinical genetic testing results may thus, in certain cases, flag the potential for an increased risk for comorbidities including neurodevelopmental delays. On the other hand, pathogenic variants historically identified through syndromic phenotypes may have cardiac phenotypes without classic extracardiac expression ${ }^{14}$. For most individual genetic predispositions however, the extent of the disease spectrum is yet unknown. Delineating genotype-associated clinical traits, and understanding their penetrance, will be essential for genetic counselling, familial risk assessments, and informing outcome.

Identifying the genetic etiologies of TOF can improve clinical management, by providing information on outcomes and risks related to the variant, in addition to those related to the cardiac anatomical severity and other clinical parameters ${ }^{13,48,49}$. After the surgical repair of TOF, heart failure and arrhythmias are leading causes of morbidity, impaired quality of life, and mortality. Genetic factors that can affect the molecular and structural properties of the heart and vasculature may play a role. In this study, 16 out of 811 probands (2.0\%) were identified to have pathogenic/likely pathogenic variants that could affect cardiac surveillance and management recommendations (Table S7). Longitudinal clinical data will be needed to characterize adverse or favourable outcomes of patient populations that include such genetic variant data, in order to identify predictive markers and to inform preventive and therapeutic interventions, as part of precision medicine.

Advantages and limitations: We analyzed genetic risk variants in the largest available exome dataset of individuals with TOF. We prioritized variants with sufficient evidence for pathogenicity, according to consensus clinical guidelines ${ }^{25}$, in order to increase the "signal-to-noise ratio" in the reporting of single gene defects. In contrast to primarily statistical approaches, such as that previously applied to this cohort ${ }^{20}$, this clinical strategy helped enable us to take into account the expected genetic and allelic heterogeneity of pathogenic variants in TOF. For example, 18 genes were identified with only one pathogenic/likely pathogenic variant in this cohort. The lack of variant segregation data and the 
medRxiv preprint doi: https://doi.org/10.1101/2021.02.17.21251707; this version posted February 19, 2021. The copyright holder for this preprint (which was not certified by peer review) is the author/funder, who has granted medRxiv a license to display the preprint in perpetuity. It is made available under a CC-BY-ND 4.0 International license .

Reuter et al.

TOF clinical variants \& interacting network

inaccessibility of individual clinical information, such as anatomical subtypes, disease progression, associated features, or age for this cohort ${ }^{20}$, however limited the interpretation of the findings. Our analyses were also restricted to rare small sequence variants and insertions/deletions in regions targeted by exome sequencing, typically involving 95\% of exonic regions. Despite their established contribution to $\mathrm{CHD}^{14}$, the exome data available did not allow us to assess structural aberrations, such as rare copy number variants; individuals with typical 22q11.2 deletions were however excluded ${ }^{20}$. All variants reported here were identified in heterozygous state, passed internal quality metrics, and were visually validated in the aligned sequencing reads, however we could not confirm their accuracy by Sanger sequencing.

Conclusions: We studied the largest published exome sequencing dataset of patients with TOF, interpreting variants from the perspective of clinical pathogenicity. The identified genetic results add evidence for a major contribution of VEGF/Notch dysregulation and provide novel findings for functionally interacting protein networks relevant to the pathomechanism of TOF. We anticipate that clinical genomic sequencing, especially where capability of detecting structural variants is included, will become an essential component for assessing risks and outcomes in patients with $\mathrm{CHD}^{22}$. Re-analysis of existing datasets is warranted, as our knowledge to identify and interpret disease-related variants continuously evolves.

Acknowledgments: Sequence data has been accessed through the European Genome-phenome Archive (EGA), which is hosted by the EBI and the CRG, under accession number EGAS00001003302 (https://egaarchive.org). We thank Page et al. ${ }^{20}$ for allowing us access to the data, and the patients and their families for participation in this research effort. We thank the staff at The Centre for Applied Genomics (TCAG), a node of CGEn, for support in data analysis.

Funding Sources: S.W.S. is funded by the Glaxo Smith Kline-CIHR Chair in Genome Sciences at the University of Toronto and The Hospital for Sick Children. A.S.B. holds the Dalglish Chair in 22q11.2 Deletion Syndrome at the University Health Network and University of Toronto. B.D.K. is supported by a British Heart Foundation Personal Chair.

Disclosures: S.W.S. serves on the Scientific Advisory Committees of Population Diagnostics and Deep Genomics, and is a Highly Cited Academic Advisor to the King Abdulaziz University. The other authors declare no conflicts of interest. 
medRxiv preprint doi: https://doi.org/10.1101/2021.02.17.21251707; this version posted February 19, 2021. The copyright holder for this preprint

(which was not certified by peer review) is the author/funder, who has granted medRxiv a license to display the preprint in perpetuity.

It is made available under a CC-BY-ND 4.0 International license .

Reuter et al.

TOF clinical variants \& interacting network

Figures and legends:

Confirmed CHD genes:

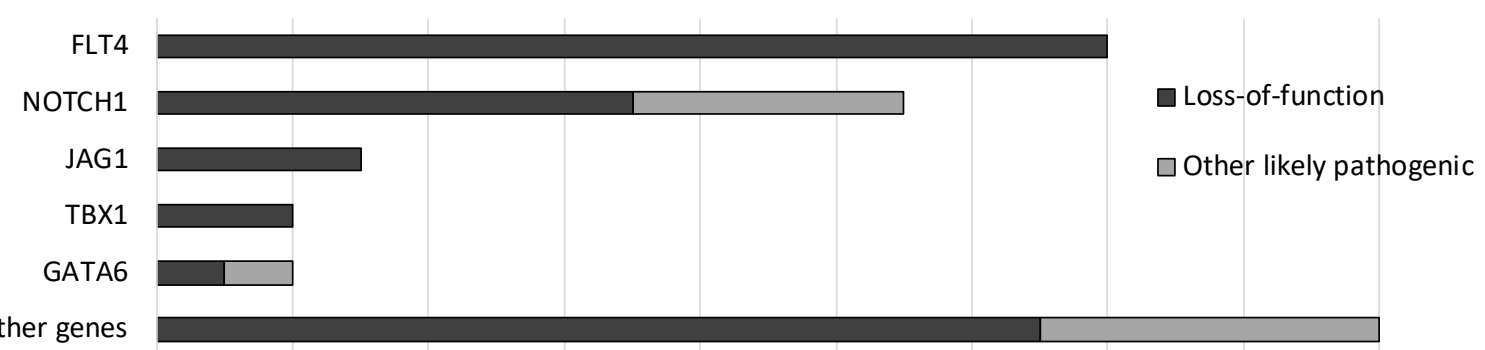

Emerging candidate genes for CHD/TOF:

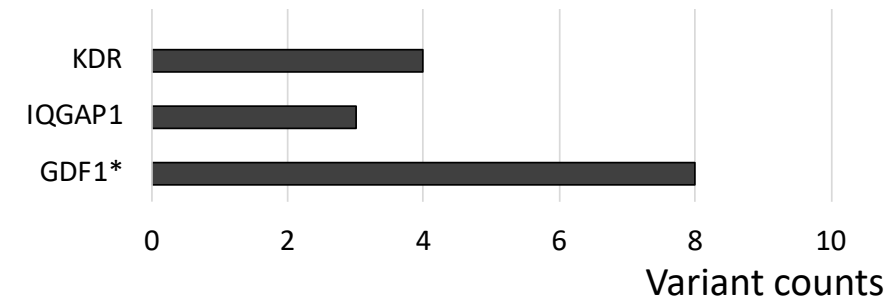

Figure 1: Clinically relevant variants associated with congenital heart disease (CHD), identified in exome sequencing data of $\mathbf{n}=\mathbf{8 1 1}$ probands with tetralogy of Fallot (TOF). Likely pathogenic loss-offunction and missense variants meeting ACMG criteria for clinical relevance (pathogenic or likely pathogenic, $n=50$ ) in 23 recognized CHD genes were identified in 49 probands. Loss-of-function variants $(n=15)$ in 3 emerging candidate genes for CHD/TOF were identified in another 15 probands. Variant and gene details are provided in Tables $\mathrm{S} 2$ and $\mathrm{S} 3$, respectively, and Figure $\mathrm{S} 1$ provides details of $K D R$ variants. Additional variants of uncertain significance are provided in Table S5.

* Note: Comprehensive assessment of gene GDF1 was not possible due to insufficient coverage of this locus with the exome sequencing data available. 
medRxiv preprint doi: https://doi.org/10.1101/2021.02.17.21251707; this version posted February 19, 2021. The copyright holder for this preprint (which was not certified by peer review) is the author/funder, who has granted medRxiv a license to display the preprint in perpetuity. It is made available under a CC-BY-ND 4.0 International license .

Reuter et al.

TOF clinical variants \& interacting network

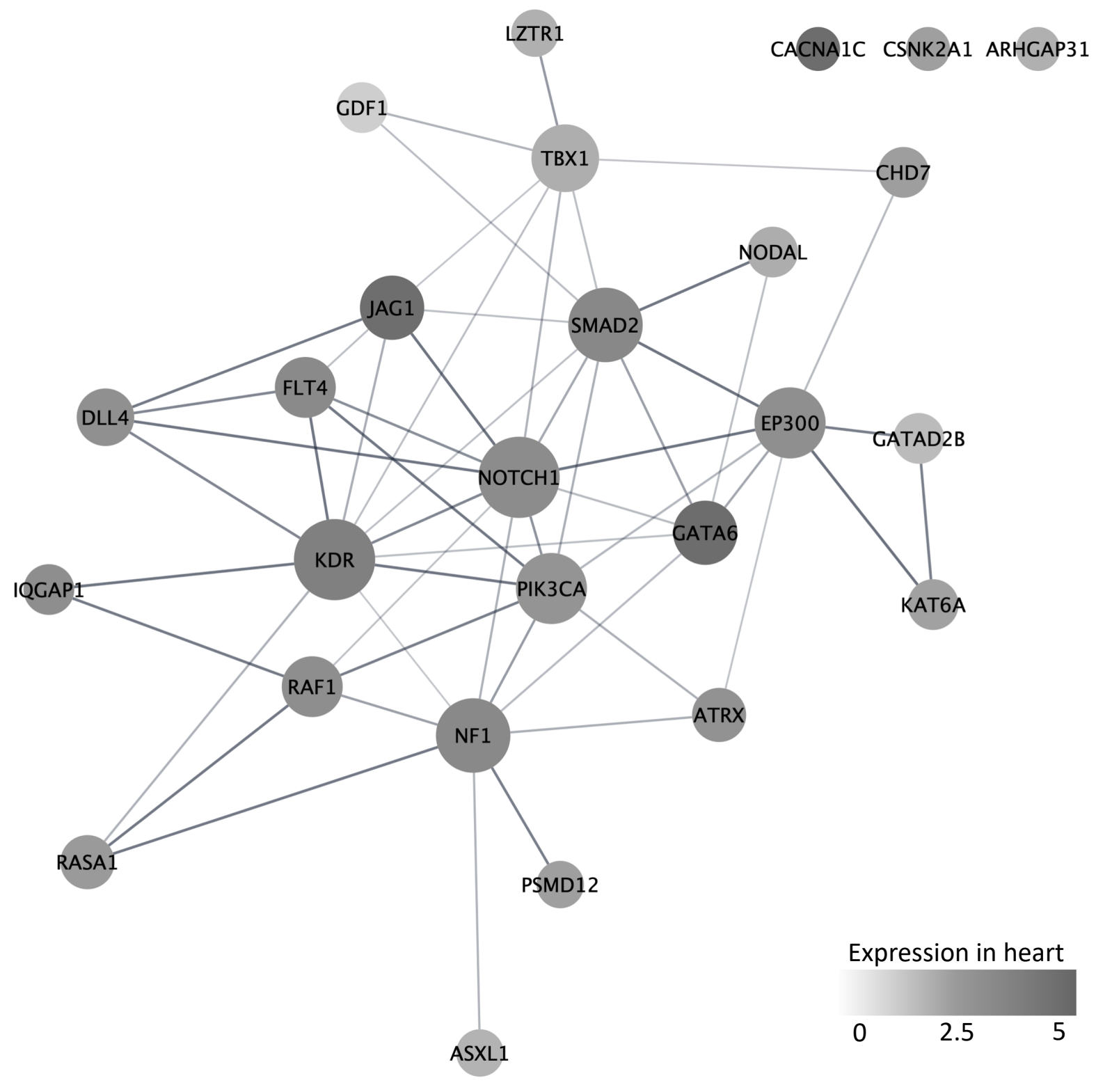

Figure 2: Functionally interacting proteins encoded by confirmed genes $(n=23)$ and emerging candidate genes $(n=3)$ for CHD/TOF identified in $\mathbf{n}=\mathbf{8 1 1}$ individuals with TOF. Network analysis was performed using Cytoscape, STRING and the 26 genes identified from exome sequencing of this cohort (STRING interaction enrichment $p$ value 3.3E-16; see text for details). Node sizes (circles) represent the connectivity (numbers of edges to other proteins). Node greyscales represent the degree of expression from the Gene Expression Omnibus (GEO) database (heart tissue). Edge widths represent the confidence (strength of data support). 23 of the 26 genes form an interactive network with VEGFR2 (gene KDR) and NOTCH1 as central nodes, each connecting directly with 11 other proteins. Figure S2 shows a slightly extended network (e.g., NOTCH2 with 5 interactions) after adding data from an independent TOF 
medRxiv preprint doi: https://doi.org/10.1101/2021.02.17.21251707; this version posted February 19, 2021. The copyright holder for this preprint (which was not certified by peer review) is the author/funder, who has granted medRxiv a license to display the preprint in perpetuity. It is made available under a CC-BY-ND 4.0 International license .

Reuter et al.

TOF clinical variants \& interacting network

cohort. Not shown are four proteins of uncertain relevance to TOF, but with likely pathogenic variants

observed in the sample (Table S6) that connect to the network: GLI2 (NOTCH1, SMAD2, JAG1, PSMD12),

APC (NOTCH1, IQGAP1, PSMD12, CSNK2A1), TCF12 (NOTCH1, SMAD2, EP300), POLR1A (EP300). 
medRxiv preprint doi: https://doi.org/10.1101/2021.02.17.21251707; this version posted February 19, 2021. The copyright holder for this preprint (which was not certified by peer review) is the author/funder, who has granted medRxiv a license to display the preprint in perpetuity. It is made available under a CC-BY-ND 4.0 International license .

Reuter et al.

TOF clinical variants \& interacting network

\section{References:}

1. Liu Y, Chen S, Zuhlke L, Black GC, Choy MK, Li N and Keavney BD. Global birth prevalence of congenital heart defects 1970-2017: updated systematic review and meta-analysis of 260 studies. Int J Epidemiol. 2019;48:455-463.

2. Bailliard F and Anderson RH. Tetralogy of Fallot. Orphanet J Rare Dis. 2009;4:2.

3. Diaz-Frias J and Guillaume M. Tetralogy of Fallot StatPearls Treasure Island (FL); 2020.

4. Neill CA and Clark EB. Tetralogy of Fallot. The first 300 years. Tex Heart Inst J. 1994;21:272-9.

5. Gelb BD. History of Our Understanding of the Causes of Congenital Heart Disease. Circ Cardiovasc Genet. 2015;8:529-36.

6. Stefanescu Schmidt AC, DeFaria Yeh D, Tabtabai S, Kennedy KF, Yeh RW and Bhatt AB. National Trends in Hospitalizations of Adults With Tetralogy of Fallot. Am J Cardiol. 2016;118:906-911.

7. Agarwal A, Thombley R, Broberg CS, Harris IS, Foster E, Mahadevan VS, John A, Vittinghoff E, Marcus GM and Dudley RA. Age- and Lesion-Related Comorbidity Burden Among US Adults With Congenital Heart Disease: A Population-Based Study. J Am Heart Assoc. 2019;8:e013450.

8. Marelli AJ, Ionescu-Ittu R, Mackie AS, Guo L, Dendukuri N and Kaouache M. Lifetime prevalence of congenital heart disease in the general population from 2000 to 2010. Circulation. 2014;130:749-56.

9. Diller GP, Kempny A, Alonso-Gonzalez R, Swan L, Uebing A, Li W, Babu-Narayan S, Wort SJ, Dimopoulos K and Gatzoulis MA. Survival Prospects and Circumstances of Death in Contemporary Adult Congenital Heart Disease Patients Under Follow-Up at a Large Tertiary Centre. Circulation. 2015;132:2118-25.

10. Lahiri S, Gil W, Daria S, Joshua G, Parul J, Redmond B and Elizabeth W. Genetic abnormalities/syndromes significantly impact perioperative outcomes of conotruncal heart defects. Ann Pediatr Cardiol. 2020;13:38-45.

11. Formigari R, Michielon G, Digilio MC, Piacentini G, Carotti A, Giardini A, Di Donato RM and Marino B. Genetic syndromes and congenital heart defects: how is surgical management affected? Eur J Cardiothorac Surg. 2009;35:606-14.

12. Russell MW, Chung WK, Kaltman JR and Miller TA. Advances in the Understanding of the Genetic Determinants of Congenital Heart Disease and Their Impact on Clinical Outcomes. J Am Heart Assoc. 2018;7.

13. van Mil S, Heung T, Malecki S, Van L, Chang J, Breetvelt E, Wald R, Oechslin E, Silversides C and Bassett AS. Impact of a 22q11.2 Microdeletion on Adult All-Cause Mortality in Tetralogy of Fallot Patients. Can J Cardiol. 2020;36:1091-1097.

14. Costain G, Silversides CK and Bassett AS. The importance of copy number variation in congenital heart disease. NPJ Genom Med. 2016;1:16031.

15. Morgenthau A and Frishman WH. Genetic origins of tetralogy of Fallot. Cardiol Rev. 2018;26:86-

92.

16. Lahm H, Schon P, Doppler S, Dressen M, Cleuziou J, Deutsch MA, Ewert P, Lange R and Krane M. Tetralogy of Fallot and Hypoplastic Left Heart Syndrome - Complex Clinical Phenotypes Meet Complex Genetic Networks. Curr Genomics. 2015;16:141-58.

17. Silversides CK, Lionel AC, Costain G, Merico D, Migita O, Liu B, Yuen T, Rickaby J, Thiruvahindrapuram B, Marshall CR, Scherer SW and Bassett AS. Rare copy number variations in adults with tetralogy of Fallot implicate novel risk gene pathways. PLoS Genet. 2012;8:e1002843.

18. Reuter MS, Jobling R, Chaturvedi RR, Manshaei R, Costain G, Heung T, Curtis M, Hosseini SM, Liston E, Lowther C, Oechslin E, Sticht H, Thiruvahindrapuram B, Mil SV, Wald RM, Walker S, Marshall CR, Silversides CK, Scherer SW, Kim RH and Bassett AS. Haploinsufficiency of vascular endothelial growth factor related signaling genes is associated with tetralogy of Fallot. Genet Med. 2019;21:1001-1007. 
medRxiv preprint doi: https://doi.org/10.1101/2021.02.17.21251707; this version posted February 19, 2021. The copyright holder for this preprint (which was not certified by peer review) is the author/funder, who has granted medRxiv a license to display the preprint in perpetuity. It is made available under a CC-BY-ND 4.0 International license .

Reuter et al.

TOF clinical variants \& interacting network

19. Manshaei R, Merico D, Reuter MS, Engchuan W, Mojarad BA, Chaturvedi R, Heung T, Pellecchia G, Zarrei M, Nalpathamkalam T, Khan R, Okello JBA, Liston E, Curtis M, Yuen RKC, Marshall CR, Jobling RK, Oechslin E, Wald RM, Silversides CK, Scherer SW, Kim RH and Bassett AS. Genes and Pathways Implicated in Tetralogy of Fallot Revealed by Ultra-Rare Variant Burden Analysis in 231 Genome Sequences. Front Genet. 2020;11:957.

20. Page DJ, Miossec MJ, Williams SG, Monaghan RM, Fotiou E, Cordell HJ, Sutcliffe L, Topf A, Bourgey M, Bourque G, Eveleigh R, Dunwoodie SL, Winlaw DS, Bhattacharya S, Breckpot J, Devriendt K, Gewillig M, Brook JD, Setchfield KJ, Bu'Lock FA, O'Sullivan J, Stuart G, Bezzina CR, Mulder BJM, Postma AV, Bentham JR, Baron M, Bhaskar SS, Black GC, Newman WG, Hentges KE, Lathrop GM, SantibanezKoref $\mathrm{M}$ and Keavney BD. Whole Exome Sequencing Reveals the Major Genetic Contributors to Nonsyndromic Tetralogy of Fallot. Circ Res. 2019;124:553-563.

21. Jin SC, Homsy J, Zaidi S, Lu Q, Morton S, DePalma SR, Zeng X, Qi H, Chang W, Sierant MC, Hung WC, Haider S, Zhang J, Knight J, Bjornson RD, Castaldi C, Tikhonoa IR, Bilguvar K, Mane SM, Sanders SJ, Mital S, Russell MW, Gaynor JW, Deanfield J, Giardini A, Porter GA, Jr., Srivastava D, Lo CW, Shen Y, Watkins WS, Yandell M, Yost HJ, Tristani-Firouzi M, Newburger JW, Roberts AE, Kim R, Zhao H, Kaltman JR, Goldmuntz E, Chung WK, Seidman JG, Gelb BD, Seidman CE, Lifton RP and Brueckner M. Contribution of rare inherited and de novo variants in 2,871 congenital heart disease probands. Nat Genet. 2017;49:1593-1601.

22. Reuter MS, Chaturvedi RR, Liston E, Manshaei R, Aul RB, Bowdin S, Cohn I, Curtis M, Dhir P, Hayeems RZ, Hosseini SM, Khan R, Ly LG, Marshall CR, Mertens L, Okello JBA, Pereira SL, Raajkumar A, Seed M, Thiruvahindrapuram B, Scherer SW, Kim RH and Jobling RK. The Cardiac Genome Clinic: implementing genome sequencing in pediatric heart disease. Genet Med. 2020;22:1015-1024.

23. Jia Y, Louw JJ, Breckpot J, Callewaert B, Barrea C, Sznajer Y, Gewillig M, Souche E, Dehaspe L, Vermeesch JR, Lambrechts $D$, Devriendt $K$ and Corveleyn $A$. The diagnostic value of next generation sequencing in familial nonsyndromic congenital heart defects. Am J Med Genet A. 2015;167A:1822-9.

24. Fotiou E, Williams S, Martin-Geary A, Robertson DL, Tenin G, Hentges KE and Keavney B. Integration of Large-Scale Genomic Data Sources With Evolutionary History Reveals Novel Genetic Loci for Congenital Heart Disease. Circ Genom Precis Med. 2019;12:442-451.

25. Richards S, Aziz N, Bale S, Bick D, Das S, Gastier-Foster J, Grody WW, Hegde M, Lyon E, Spector E, Voelkerding K, Rehm HL and Committee ALQA. Standards and guidelines for the interpretation of sequence variants: a joint consensus recommendation of the American College of Medical Genetics and Genomics and the Association for Molecular Pathology. Genet Med. 2015;17:405-24.

26. Lappalainen I, Almeida-King J, Kumanduri V, Senf A, Spalding JD, Ur-Rehman S, Saunders G, Kandasamy J, Caccamo M, Leinonen R, Vaughan B, Laurent T, Rowland F, Marin-Garcia P, Barker J, Jokinen P, Torres AC, de Argila JR, Llobet OM, Medina I, Puy MS, Alberich M, de la Torre S, Navarro A, Paschall J and Flicek P. The European Genome-phenome Archive of human data consented for biomedical research. Nat Genet. 2015;47:692-5.

27. Cordell HJ, Topf A, Mamasoula C, Postma AV, Bentham J, Zelenika D, Heath S, Blue G, Cosgrove C, Granados Riveron J, Darlay R, Soemedi R, Wilson IJ, Ayers KL, Rahman TJ, Hall D, Mulder BJ, Zwinderman AH, van Engelen K, Brook JD, Setchfield K, Bu'Lock FA, Thornborough C, O'Sullivan J, Stuart AG, Parsons J, Bhattacharya S, Winlaw D, Mital S, Gewillig M, Breckpot J, Devriendt K, Moorman AF, Rauch A, Lathrop GM, Keavney BD and Goodship JA. Genome-wide association study identifies loci on 12q24 and 13q32 associated with tetralogy of Fallot. Hum Mol Genet. 2013;22:1473-81.

28. Shannon P, Markiel A, Ozier O, Baliga NS, Wang JT, Ramage D, Amin N, Schwikowski B and Ideker T. Cytoscape: a software environment for integrated models of biomolecular interaction networks. Genome Res. 2003;13:2498-504.

29. Szklarczyk D, Gable AL, Lyon D, Junge A, Wyder S, Huerta-Cepas J, Simonovic M, Doncheva NT, Morris JH, Bork P, Jensen $\mathrm{L}$ and Mering CV. STRING v11: protein-protein association networks with 
medRxiv preprint doi: https://doi.org/10.1101/2021.02.17.21251707; this version posted February 19, 2021. The copyright holder for this preprint (which was not certified by peer review) is the author/funder, who has granted medRxiv a license to display the preprint in perpetuity. It is made available under a CC-BY-ND 4.0 International license .

Reuter et al.

TOF clinical variants \& interacting network

increased coverage, supporting functional discovery in genome-wide experimental datasets. Nucleic Acids Res. 2019;47:D607-D613.

30. Morton SU, Shimamura A, Newburger PE, Opotowsky AR, Quiat D, Pereira AC, Jin SC, Gurvitz M, Brueckner M, Chung WK, Shen Y, Bernstein D, Gelb BD, Giardini A, Goldmuntz E, Kim RW, Lifton RP, Porter GA, Jr., Srivastava D, Tristani-Firouzi M, Newburger JW, Seidman JG and Seidman CE. Association of Damaging Variants in Genes With Increased Cancer Risk Among Patients With Congenital Heart Disease. JAMA Cardiol. 2020.

31. Petrovski S, Aggarwal V, Giordano JL, Stosic M, Wou K, Bier L, Spiegel E, Brennan K, Stong N, Jobanputra V, Ren Z, Zhu X, Mebane C, Nahum O, Wang Q, Kamalakaran S, Malone C, Anyane-Yeboa K, Miller R, Levy B, Goldstein DB and Wapner RJ. Whole-exome sequencing in the evaluation of fetal structural anomalies: a prospective cohort study. Lancet. 2019;393:758-767.

32. Sevim Bayrak C, Zhang P, Tristani-Firouzi M, Gelb BD and Itan Y. De novo variants in exomes of congenital heart disease patients identify risk genes and pathways. Genome Med. 2020;12:9.

33. Karkera JD, Lee JS, Roessler E, Banerjee-Basu S, Ouspenskaia MV, Mez J, Goldmuntz E, Bowers P, Towbin J, Belmont JW, Baxevanis AD, Schier AF and Muenke M. Loss-of-function mutations in growth differentiation factor-1 (GDF1) are associated with congenital heart defects in humans. Am J Hum Genet. 2007;81:987-94.

34. Blue GM, Kirk EP, Giannoulatou E, Dunwoodie SL, Ho JW, Hilton DC, White SM, Sholler GF, Harvey RP and Winlaw DS. Targeted next-generation sequencing identifies pathogenic variants in familial congenital heart disease. J Am Coll Cardiol. 2014;64:2498-506.

35. Allanson JE and Roberts AE. Noonan Syndrome. In: M. P. Adam, H. H. Ardinger, R. A. Pagon, S. E. Wallace, L. J. H. Bean, K. Stephens and A. Amemiya, eds. GeneReviews((R)) Seattle (WA); 1993.

36. Napolitano C, Splawski I, Timothy KW, Bloise R and Priori SG. Timothy Syndrome. In: M. P. Adam, H. H. Ardinger, R. A. Pagon, S. E. Wallace, L. J. H. Bean, K. Stephens and A. Amemiya, eds.

GeneReviews((R)) Seattle (WA); 1993.

37. Tada H, Fujino N, Nomura A, Nakanishi C, Hayashi K, Takamura M and Kawashiri MA.

Personalized medicine for cardiovascular diseases. J Hum Genet. 2021;66:67-74.

38. Dainis AM and Ashley EA. Cardiovascular Precision Medicine in the Genomics Era. JACC Basic Transl Sci. 2018;3:313-326.

39. van den Akker NM, Molin DG, Peters PP, Maas S, Wisse LJ, van Brempt R, van Munsteren CJ, Bartelings MM, Poelmann RE, Carmeliet P and Gittenberger-de Groot AC. Tetralogy of fallot and alterations in vascular endothelial growth factor-A signaling and notch signaling in mouse embryos solely expressing the VEGF120 isoform. Circ Res. 2007;100:842-9.

40. Eyries M, Montani D, Girerd B, Favrolt N, Riou M, Faivre L, Manaud G, Perros F, Graf S, Morrell NW, Humbert $M$ and Soubrier F. Familial pulmonary arterial hypertension by KDR heterozygous loss of function. Eur Respir J. 2020;55.

41. Swietlik EM, Greene D, Zhu N, Megy K, Cogliano M, Rajaram S, Pandya D, Tilly T, Lutz KA, Welch CCL, Pauciulo MW, Southgate L, Martin JM, Treacy CM, Penkett CJ, Stephens JC, Bogaard HJ, Church C, Coghlan G, Coleman AW, Condliffe R, Eichstaedt CA, Eyries M, Gall H, Ghio S, Girerd B, Grunig E, Holden S, Howard L, Humbert M, Kiely DG, Kovacs G, Lordan J, Machado RD, Mackenzie Ross RV, McCabe C, Moledina S, Montani D, Olschewski H, Pepke-Zaba J, Price L, Rhodes CJ, Seeger W, Soubrier F, Suntharalingam J, Toshner MR, Vonk Noordegraaf A, Wharton J, Wild JM, Wort SJ, Lawrie A, Wilkins MR, Trembath RC, Shen Y, Chung WK, Swift AJ, Nichols WC, Morrell NW and Graf S. Bayesian Inference Associates Rare KDR Variants with Specific Phenotypes in Pulmonary Arterial Hypertension. Circ Genom Precis Med. 2020.

42. Dimopoulos K, Condliffe R, Tulloh RMR, Clift P, Alonso-Gonzalez R, Bedair R, Chung NAY, Coghlan G, Fitzsimmons S, Frigiola A, Howard LS, Jenkins P, Kenny D, Li W, MacDonald ST, McCabe C, Oliver JJ, Spence MS, Szantho GV, von Klemperer K, Wilson DG, Wort SJ and Committee CS. Echocardiographic 
medRxiv preprint doi: https://doi.org/10.1101/2021.02.17.21251707; this version posted February 19, 2021. The copyright holder for this preprint (which was not certified by peer review) is the author/funder, who has granted medRxiv a license to display the preprint in perpetuity. It is made available under a CC-BY-ND 4.0 International license .

Reuter et al.

TOF clinical variants \& interacting network

Screening for Pulmonary Hypertension in Congenital Heart Disease: JACC Review Topic of the Week. J Am Coll Cardiol. 2018;72:2778-2788.

43. White CD, Erdemir HH and Sacks DB. IQGAP1 and its binding proteins control diverse biological functions. Cell Signal. 2012;24:826-34.

44. van den Akker NM, Caolo V and Molin DG. Cellular decisions in cardiac outflow tract and coronary development: an act by VEGF and NOTCH. Differentiation. 2012;84:62-78.

45. Jain R, Rentschler S and Epstein JA. Notch and cardiac outflow tract development. Ann N Y Acad Sci. 2010;1188:184-90.

46. Luxan G, D'Amato G, MacGrogan D and de la Pompa JL. Endocardial Notch Signaling in Cardiac Development and Disease. Circ Res. 2016;118:e1-e18.

47. Lambrechts D, Devriendt K, Driscoll DA, Goldmuntz E, Gewillig M, Vlietinck R, Collen D and Carmeliet P. Low expression VEGF haplotype increases the risk for tetralogy of Fallot: a family based association study. J Med Genet. 2005;42:519-22.

48. Michielon G, Marino B, Formigari R, Gargiulo G, Picchio F, Digilio MC, Anaclerio S, Oricchio G, Sanders SP and Di Donato RM. Genetic syndromes and outcome after surgical correction of tetralogy of Fallot. Ann Thorac Surg. 2006;81:968-75.

49. Villafane J, Feinstein JA, Jenkins KJ, Vincent RN, Walsh EP, Dubin AM, Geva T, Towbin JA, Cohen MS, Fraser C, Dearani J, Rosenthal D, Kaufman B, Graham TP, Jr., Adult C and Pediatric Cardiology Section ACoC. Hot topics in tetralogy of Fallot. J Am Coll Cardiol. 2013;62:2155-66. 